Haris : Peningkatan Pengetahuan Lanjut Usia melalui Pendidikan Kesehatan

\title{
Peningkatan Pengetahuan Lanjut Usia melalui Pendidikan Kesehatan dengan Menggunakan Media Power Point
}

\author{
Haris, Muh Aris, Muliyadi \\ Akademi Keperawatan Kaltara Tarakan \\ Email : hariskasuhe@gmail.com
}

\begin{abstract}
Abstrak
Lanjut usia merupakan bagian akhir dari tahapan perkembangan manusia. Lanjut usia merupakan salah satu kelompok rentan terkena penyakit. Ketika memasuki tahap lanjut usia dibutuhkan pengetahuan untuk meningkatkan dan menjaga kesehatan. Pemberian pendidikan Kesehatan dapat meningkatkan pengetahuan lansia. Penggunaan power point sebagai media memiliki kelebihan yaitu selain dapat menampilkan gambar, power point juga dapat menampilkan audiovisual. Tujuan pengabdian kepada masyarakat ini adalah untuk mengetahui pengaruh pemberian penyuluhan kesehatan dengan menggunakan media power point terhadap pengetahuan lanjut usia. Kuesioner yang digunakan merupakan rancangan peneliti mencakup upaya untuk menjaga kesehatan selama masa lanjut usia yang sudah dilakukan face validity. Saat dilakukan pre test, mean skor pengetahuan lanjut usia adalah 22,73. Kemudian dilakukan pendidikan kesehatan selama 30 menit dengan ceramah dan menggunakan media powert point, materi yang disampaikan adalah kategori lanjut usia, masalah kesehatan saat lanjut usia dan cara menjaga kesehatan. kemudian dilakukan post post test dan didapatkan mean skor 24,47. Hasil mean skor pengetahuan lanjut usia tersebut memiliki distribusi normal yang berdasarkan hasil uji Kolmogorov-Smirnov dengan nilai 0.364. Hasil uji t-test menunjukkan 0.000 yang menunjukan adanya perbedaan antara mean skor pengetahuan lanjut usia sebelum dan sesudah dilakukan penyuluhan kesehatan dengan menggunakan media power point.Berdasarkan hasil tersebut dapat disimpulkan adanya pengaruh pemberian penyuluhan dengan menggunakan media power point terhadap pengetahuan lansia.
\end{abstract}

Kata kunci : Kesehatan Lansia, media powerpoint, penyuluhan kesehatan.

\begin{abstract}
Elderly is the final part of the stages of human development and it is one of the groups vulnerable to disease. When entering the elderly stage, knowledge is needed to improve and maintain health. Providing health education can increase knowledge of elderly. The use of power point as a media has advantages, in addition to being able to display images, power point can also display audiovisual. The purpose of community service is to determine the effect of providing health education by using power point media on elderly knowledge. The questionnaire used was the design of the researchers including efforts to maintain health during the elderly that had been carried out face validity. When pre-tested, the mean score of elderly knowledge was 22.73. Then health education was conducted for 30 minutes by lecturing and using media powert point, the material presented was the elderly category, health problems when elderly and how to maintain health. Then researcher did a post-test and obtained mean score 24.47. The results of the mean score of elderly knowledge had a normal distribution based on the Kolmogorov-Smirnov test results with a value of 0.364. The results of the t-test showed 0,000 which showed a difference between the mean scores of elderly knowledge before and after health education using power point media. Based on these results it can be concluded that there was an influence of providing education using power point media on elderly knowledge.
\end{abstract}

Keywords : Elderly care, health educaton, power point media. 


\section{Pendahuluan}

Proses menua merupakan tahap akhir dalam proses perkembangan hidup manusia. Menurut Undang-undang RI nomor 13 tahun 1998 tentang kesejahteraan lansia, batasan umur lanjut usia atau disingkat lansia adalah ketika seseorang berusia 60 tahun keatas. Jumlah populasi lansia saat ini semakin meningkat. Menurut World Health Organization (WHO) jumlah populasi dengan lanjut usia secara global tahun 2015 adalah 12\% dari seluruh penduuduk dunia dan ini akan meningkat menjadi $22 \%$ pada tahun 2050. Di Indonesia menurut Kementerian kesehatan (Kemenkes) RI jumlah populasi lansia secara nasional pada tahun 2017 adalah 9\% dari jumlah penduduk Indonesia atau sebesar 23,66 juta lansia. Usia harapan hidup secara global tertinggi di dunia terdapat di Jepang yaitu 83,7 tahun. sementara di Indonesia usia harapan hidup pada tahun 2017 menurut Kemenkes mencapai 71 tahun.

Konsekuensi dengan bertambahnya jumlah populasi lansia, maka dibutuhkan perhatian serius dari semua pihak karena jumlah tersebut bisa menjadi beban bagi negara apabila kondisi lansia tidak produktif, tidak mandiri dan dalam kondisi sakit. Berdasarkan data Survey ekonomi nasional (Susenas) tahun 2015 menyebutkan bahwa sebesar 28,62\% dari populasi lansia di Indonesia dalam kondisinya tidak sehat. Penyakit yang dialami lansia berawal dari penurunan fungsi tubuh sehingga sistem pertahanan tubuh lansia menurun yang dapat memicu terjadinya penyakit. Beberapa kondisi yang sering dijumpai pada lansia adalah mal nutrisi, gangguan keseimbangan, kebingungan mendadak dan lain lain (Kemenkes, 2015). Lansia juga rentan menderita beberapa penyakit tidak menular (PTM). Beberapa faktor risiko penyakit tidak menular seperti merokok, tidak mengkonsumsi buah dan sayuran, mengkonsumsi alkohol serta malas melakukan aktifitas fisik (olahraga). Lima masalah kesehatan yang dialami lansia adalah hipertensi, athritis, strok, prenyakit paru obstruksi kronik (PPOK) dan diabetes mellitus.

Pemeliharan kesehatan lansia menurut Undang-Undang RI nomor 36 tahun 2009 tentang kesehatan diarahkan untuk menjaga agar lansia tetap sehat dan produktif baik secara sosial maupun ekonomi. Upaya pemeliharaan kesehatan lansia tersebut bertujuan untuk meningkatkan derajat kesehatan lansia. Untuk mencapai tujuan pemelihatan tersebut 
Haris : Peningkatan Pengetahuan Lanjut Usia melalui Pendidikan Kesehatan

maka keterlibatan lintas sektoral sangat dibutuhkan baik dari kementerian kesehatan, kementerian sosial dan pemerintah daerah. Kementrian kesehatan RI, mengeluarkan kebijakan penyediaan sarana dan prasarana kesehatan yang ramah bagi lansia, meningkatkan upaya rujukan di rumah sakit bagi lansia. Pada tahun 2017, tatanan fasilitas kesehatan dasar terdapat program pelayanan kesehatan santun lansia yang telah dilaksanakan oleh 37,1\% Puskesmas di Indonesia, dan terdapat 80.353 ribu posyandu lansia yang tersebar di seluruh Indonesia.

Beradasarkan Badan Statistik Kalimantan Utara, jumlah lansia di Kalimantan Utara tahun 2017 sebesar 41.041 jiwa atau sebesar 5,94\% dari total penduduk Kalimantan Utara. Untuk Kota Tarakan persentase penduduk lanjut usia yang berusia diatas 65 tahun di kota Tarakan terus meningkat dalam 3 tahun terakhir. Pada tahun 2017 terdapat 2,76\% dari jumlah total penduduk Tarakan atau sekitar 6.983 jiwa. Kelurahan Mamburungan Timur merupakan salah satu wilayah timur Kota Tarakan dan telah ditetapkan oleh Kelurahan Mamburungan Timur, Puskesmas Mamburungan dan Akademi Keperawatan Kaltara sebagai wilayah binaan. Hasil laporan pendataan awal oleh mahasiswa pada bulan Maret 2019 jumlah lansia di kelurahan Mambrungan Timur adalah 95 orang atau 4,66\% dari jumlah penduduk Kelurahan Mamburungan Timur. Berdasarkan hasil laporan pendataan bahwa terdapat $86 \%$ lansia tidak atau jarang melakukan cek kesehatan secara rutin di pelayanan Kesehatan dan berdasarkan hasil wawancara dengan petugas puskesmas Mamburungan dan pihak kelurahan Mamburungan Timur tidak ada posyandu lansia di wilayah Mamburungan Timur.

Salah satu upaya yang dilakukan untuk mempertahankan dan meningkatkan kesehatan masyarakat adalah melalui kegiatan promosi kesehatan dalam bentuk pendidikan kesehatan. Menurut Kemenkes RI (2011) promosi kesehatan bertujuan untuk meningkatkan kemampuan masyarakat melalui pembelajaran dari oleh dan untuk masyarakat sesuai dengan kondisi sosial budaya setempat dan didukung dengan kebijakan publik yang berwawasan kesehatan. Pemberian informasi kesehatan selain dapat meningkatkan pengetahuan hasil yang diharapkan adalah perubahan perilaku. Menurut Haber (2010) pendidikan kesehatan yang diberikan dapat menjadi titik awal untuk perubahan perilaku hidup sehat tidak terkecuali pada lansia. 
Haris : Peningkatan Pengetahuan Lanjut Usia melalui Pendidikan Kesehatan

Dalam kegiatan pendidikan kesehatan yang terstruktur dapat menambah pengetahuan peserta yang mengikuti penyuluhan. Seperti dalam pendidikan kesehatan yang dilakukan posyandu dengan sasaran ibu yang memiliki balita dapat meningkatkan pengetahuan dan sikap ibu tentang imunisasi dasar (Simanjuntak dan Nurnisa, 2019). Sementara untuk lansia, keberadaan posyandu lansia sangat menunjang pelaksanaan kegiatan yang dapat meningkatkan pengetahuan tentang kesehatan lansia, dapat mempertahankan kebugaran fisik serta kesehatan psikologis lansia melalui kegiatan pendampingan posyandu lansia (Puspita, Nurdin dan Saleh, 2019)

Dalam persiapan pelaksanaan pendidikan kesehatan yang menentukan keberhasilan penyuluhan kesehatan adalah penggunaan media. Media dalam Kamus Besar Bahasa Indonesia (KBBI) sebagai salah satu sarana komunikasi. Media digunakan untuk memudahkan penyampaian informasi. Dalam promosi kesehatan, media digunakan untuk memudahkan menyampaikan informasi kesehatan. Menurut Direktorat promosi kesehatan dan pemberdayaan masyarakat Kemenkes RI, media promosi kesehatan digunakan dapat berbasis kertas (print out) seperti brosur, poster, banner sementara berupa dokumen seperti materi, peraturan, publikasi kemudian media dengan audio visul berupa film pendek, infografis dan media berbasis daring dan media sosial berupa aplikasi promosi kesehatan, memanfaatkan sosial media seperti facebook, youtube, instagram, whatsapp dan lain sebagianya.

Power point sering digunakan sebagai media pengajaran termasuk dalam pemberian pendidikan kesehatan. Menurut Brock and Joglekar (2011) penggunaan power point sangat dianjurkan dalam presentasi dan pengajaran, powert point dapat mencatumkan gambar, foto, bagan, grafik, suara (audio visual) dan animasi bila dibandingkan dengan penggunaan media lain. Penggunaan media dalam pendidikan kesehatan memiliki kelebihan dan kekurangan masing-masing, tergantung pada tujuan dan sasaran penyuluhan kesehatan. Penggunaan power point memudahkan untuk pemberian materi penyuluhan kesehatan karena melalui power point beberapa media penyuluhan dapat dipadukan seperti poster, brosur, namun kekurangan media power point hanya bisa digunakan saat presentasi dan tidak bisa dipajan seperti poster atau banner. Menurut Khoirun (2014) penggunaan power point dalam pendidikan kesehatan lebih efektif dari penggunaan leaflet, mean pengetahuan 
Haris : Peningkatan Pengetahuan Lanjut Usia melalui Pendidikan Kesehatan

dengan menggunakan power point lebih besar dari mean pengetahuan dengan menggunakan leaflet.

Informasi dari kelurahan Mamburungan timur dan perawat Puskesmas Mamburungan kegiatan penyuluhan kesehatan pada lansia belum pernah dilakukan dalam kurung waktu tiga tahun terakhir. Tujuan pengabdian masyarakat ini adalah untuk melihat pengaruh pemberian penyuluhan kesehatan dengan media power point terhadap pengetahuan lanjut usia tentang kesehatan lansia. Manfaat yang didapatkan oleh lanjut usia setelah mengikuti kegiatan pengabdian masyarakat adalah pengetahuan yang bertambah tentang menjaga kesehatan di masa lanjut usia.

\section{Metode}

Kegiatan pengabdian pada masyarakat ini melibatkan mahasiswa yang tergabung dalam panitia project social oleh lembaga kemahasiswaan Akademi Keperawatan Kaltara dan perwakilan mahasiswa yang sedang menjalankan praktek kerja lapangan di kelurahan Mamburungan Timur. Pelaksanaan pengabdian pada masyarakat diawali dengan pengurusan perizinan di kantor kelurahan Mamburungan Timur, pengurusan tempat, mahasiswa melakukan pendataan awal tentang kesehatan lansia di 11 RT sekaligus mengkoordinasikan dengan ketua RT tentang keterlibatan lansia untuk kegiatan pengabdian pada masyarakat, penulis dan tim menyiapkan keperluan kegiatan untuk penyuluhan kesehatan dan skrening kesehatan lansia serta menyiapkan materi penyuluhan.

Kuesioner yang digunakan adalah kuesioner kesehatan lansia yang merupakan $\mathrm{h}$ hasil rancangan penulis yang bertujuan untuk mengukur pengetahuan lansia tentang hidup sehat lansia. Kuesioner terdiri 15 item pernyataan dan telah dilakukan face validity terhadap 5 responden lansia yang mengatakan isi kuesioner mudah dipahami dan 3 diantaranya lansia tersebut memberikan masukan seperti merubah istilah medis ke dalam bahasa yang mudah dipahami. Pernyataan dalam kuesioner tersebut mencakup batasan umur seseorang dikatakan lansia, aktifitas yang diperbolehkan untuk lansia, waktu yang tepat untuk memeriksakan kesehatan bagi lansia, nutrisi untuk lansia serta penyakit dan keluhan yang umumnya dialami lansia. Lansia mengisi kuesioner dengan memberikan tanda centang pada pernyataan yang dianggap benar atau salah dengan didampingi oleh fasilitator dari 
Haris : Peningkatan Pengetahuan Lanjut Usia melalui Pendidikan Kesehatan

mahasiswa. Setiap pernyataan pilihannya sesuai akan diberikan skor 2 sementara yang tidak sesuai diberikan nilai 1. Angket yang terkumpul akan diberikan skor, skor maksimal adalah 30 sementara skor minimal adalah 15 .

Lansia yang terlibat dalam kegiatan pengabdian kepada masyarakat ini adalah lansia yang berada di 11 RT yang ada di Kelurahan Mamburungan Timur yang diundang secara langsung dengan melibatkan ketua RT setempat, dilakukan dua hari sebelum hari pelaksanaan. Saat hari pelaksanaan, lansia berkumpul ruang pertemuan kelurahan Mamburungan Timur dan sebelum memulai penyuluhan, dilakukan pre test kemudian dilakukan pemberian materi sehat di masa lanjut usia sekitar 30 menit dengan menggunanakan media power point. Pemateri adalah dosen pengampuh mata kuliah keperawatan gerontik (lansia) dan sering terlibat dalam kegiatan posyandu lansia. Materi yang disampaikan mencakup kategori lansia, faktor yang mempengaruhi kesehatan lansia, kesalahan persepsi tentang lansia, penyakit atau keluhan yang sering ditemukan pada lansia, aktifitas fisik untuk lansia, waktu pemeriksaan kesehatan, perilaku yang berisiko menimbulkan penyakit tidak menular dan posyandu lansia. Di dalam slide power point juga ini mencantumkan berbagai gambar yang relevan dengan materi. Selelah pemberian materi dilakukan post test. Setelah kegiatan pendidikan kesehatan dan posttest, lansia menuju meja screening yang dilakukan oleh mahasiswa. Screening yang dilakukan adalah pemeriksaan antropometri meliputi tinggi badan, berat badan dan lingkar perut, pemeriksaan tekanan darah, pengisian angket untuk mengidentifikasian faktor risiko penyakit tidak menular (PTM) dan dilakukan pemeriksaan gula darah sewaktu, asam urat dan pengecekkan kolesterol yang khusus ditujukan untuk lansia yang memiliki berat badan lebih (obesitas) atau lansia yang memiliki IMT > 25. Lembar Skrining kesehatan tentang faktor risiko penyakit tidak menular berdasarkan Kemenkes yang mengidentifikasi tentang kebiasaan merokok, kebiasan mengkonsumsi alkohol, kebiasaan mengkonsumsi makanan tinggi lemak, makanan manis, makanan asin, konsumsi buah dan sayuran, rutinitas melakukan aktifitas fisik serta kondisi psikologis seperti stress, cemas atau depresi.

Kuesioner direkap dan dilakukan perhitungan skor kemudian ditentukan nilai mean setiap lansia. Hasil rekapitulasi mean score tersebut dilakukan test normalitas data dengan menggunakan uji Kolmogorof Smirnov dan hasil yang didapatkan adalah 0.364 atau >0.05 
Haris : Peningkatan Pengetahuan Lanjut Usia melalui Pendidikan Kesehatan

yang berarti bahwa data tersebut berdistribusi normal sehingga analisa yang digunakan untuk menilai perbedaan pengetahuan sebelum dan sesudah diberikan penyuluhan kesehatan dengan menggunakan media power point, menggunakan uji t-test dependen (berpasangan) dengan nilai $p$-value $<0.05$ yang berarti ada perbedaan pretest dan post test. Apabila hasil yang didapatkan $p$-value $>0.05$ menunjukkan bahwa tidak terdapat perbedaan pretest dan post test.

\section{Hasil}

Kegiatan pengabdian pada masyarakat dilaksanakan pada Sabtu, 30 Maret 2019 di Ruang pertemuan Kantor Kelurahan Mamburungan timur. Sebelum kegiatan dilakukan senam bersama lansia, warga dan tamu undangan. Lansia yang mengikuti kegiatan pengabdian kepada masyarakat ini berjumlah 20 lansia namun yang mengikuti kegiatan secara lengkap mulai lengkap pre test, kegiatan penyuluhan dan post test adalah 15 orang, sementara 5 lansia tidak mengikuti pre test karena hadir saat kegiatan pendidikan kesehatan berlangsung, namun lansia tersebut tetap mengikuti kegiatan pengabdian masyarakat untuk peneriksaan antropometri, pemeriksaan tekanan darah serta pengecekkan gula darah dan asam urat. Untuk membantu kelancaran selama pengisian kuesioner baik pretest maupun posttest, setiap lansia dibantu oleh fasilitator dari mahasiswa yang membantu membaca dan menjelaskan maksud pernyataan dan mempersilahkan lansia untuk memilih benar atau salah dari pernyataaan tersebut.

Saat presentasi materi, lansia cukup antusias mendengarkan dan mengikuti pemaparan materi pendidikan kesehatan dengan menggunakan media power point yang mencatumkan gambar lansia sehat, kegiatan lansia, dan beberapa animasi lansia. Setiap slide dalam power point mencantumkan gambar yang sesuai dengan isi materi. Lansia memberikan respon yang positif selama pendidikan kesehatan dan beberapa di antaranya mengajukan pertanyaan mengenai materi yang disampaikan dan tidak ada lansiayang meninggalkan ruangan selama pendidikan kesehatan berlangsung. Selain lansia, dalam kegiatan pengabdian masyarakat ini juga terdapat 30 warga kelurahan Mamburungan Timur yang berusia produktif, sebagian di antaranya adalah keluarga lansia yang sedang 
mengikuti kegiatan ini dan sebagian yang lain merupakan warga di sekitaran kantor kelurahan. Kegiatan yang diikuti oleh warga usia produktif ini adalah kegiatan skrening kesehatan terutama skrening faktor risiko penyakit tidak menular.

Adapun karakteristik lansia yang mengikuti secara lengkap pengabdian kepada masyarakat ini dapat dipaparkan dalam tabel 1 berikut ini :

Tabel 1 Distribus Frekuensi Karakteristi Responden $(n=15)$

\begin{tabular}{|c|c|c|}
\hline Variabel & Frekuensi & Persentase \\
\hline \multicolumn{3}{|l|}{ Usia (tahun) } \\
\hline $60-65$ & 7 & 46,67 \\
\hline $66-70$ & 5 & 33,33 \\
\hline $71-75$ & 3 & 20,00 \\
\hline \multicolumn{3}{|l|}{ Jenis Kelamin } \\
\hline Laki-laki & 5 & 33,33 \\
\hline Perempuan & 10 & 66,67 \\
\hline \multicolumn{3}{|l|}{ Pendidikan } \\
\hline Tidak sekolah & 6 & 40,00 \\
\hline $\mathrm{SD}$ & 6 & 40,00 \\
\hline SMP & 3 & 20,00 \\
\hline SMA & 0 & 0 \\
\hline Perguruan tinggi & 0 & 0 \\
\hline \multicolumn{3}{|l|}{ Pekerjaan } \\
\hline Bekerja & 9 & 60,00 \\
\hline Tidak bekerja & 6 & 40,00 \\
\hline \multicolumn{3}{|l|}{ Indeks Massa Tubuh } \\
\hline < 18 (underweight) & 0 & 0 \\
\hline 18-24 (normal) & 9 & 60,00 \\
\hline > 24 (overweight) & 6 & 40,00 \\
\hline \multicolumn{3}{|c|}{ Hasil pengukuran tekanan darah } \\
\hline Normal & 3 & 20,00 \\
\hline Prahepertensi & 5 & 33,33 \\
\hline hipertensi & 7 & 46,67 \\
\hline
\end{tabular}

Sumber : data primer

Berdasarkan tabel 1 di atas, dapat dijelaskan bahwa hampir setengah atau 46,67\% lansia yang mengikuti kegiatan pengabdian masyarakat ini berumur pada rentang 60-65 tahun, melebihi setengah atau 66,67 \% lansia berjenis kelamin perempuan. Sementara lansia yang tidak sekolah dan lansia yang berpendidikan SD berjumlah sama yaitu 40\%, 
Haris : Peningkatan Pengetahuan Lanjut Usia melalui Pendidikan Kesehatan

lebih dari setengah atau 60\% lansia masih bekerja, lebih dari setengah atau $60 \%$ lansia memiliki Indeks massa tubuh yang normal atau berat badan yang normal sementara yang memiliki IMT > 24 atau overweight sebesar 40\% serta tidak ada lansia IMTnya di bawah normal. Hampir setengah atau 46,67\% lansia mengalami hipertensi (tekanan darah $\geq 140$ / $90 \mathrm{mmHg}$ ), pra hipertensi 33\% sementara yang memiliki tekanan darah normal sebesar $20 \%$.

Untuk mengetahui perbedaan mean skor setiap item pernyataan dalam kuesioner setelah dilakukan pretest dan posttest, diuraikan dalam tabel 2 berikut ini :

Tabel 2. Perbedaan mean skor sebelum dan sesudah pendidikan kesehatan berdasarkan item pernyataan dalam kuesioner

\begin{tabular}{|c|c|c|c|}
\hline No & Item Pernyataan & $\begin{array}{l}\text { Mean } \\
\text { pre }\end{array}$ & $\begin{array}{c}\text { Mean } \\
\text { post }\end{array}$ \\
\hline 1 & $\begin{array}{l}\text { Lanjut usia (disingkat lansia) merupakan proses alami seiring } \\
\text { dengan bertambahnya umur yaitu ketika seseorang berumur } 60 \\
\text { tahun }\end{array}$ & 25 & 25 \\
\hline 2 & $\begin{array}{l}\text { Tidak semua orang yang dilahirkan bisa memasuki masa usia } \\
\text { lanjut }\end{array}$ & 24 & 25 \\
\hline 3 & $\begin{array}{l}\text { Ketika seseorang memasuki masa lansia maka orang tersebut akan } \\
\text { sakit-sakitan }\end{array}$ & 22 & 23 \\
\hline 4 & $\begin{array}{l}\text { Ketika memasuki masa lansia, tidak dianjurkan bekerja sekalipun } \\
\text { lansia tersebut masih mampu }\end{array}$ & 22 & 24 \\
\hline 5 & $\begin{array}{l}\text { Masa lansia adalah masa dimasa seseorang harus lebih banyak } \\
\text { beristrahat di rumah }\end{array}$ & 23 & 24 \\
\hline 6 & Lansia memeriksakan kesehatannya hanya pada saat ada keluhan & 23 & 24 \\
\hline 7 & $\begin{array}{l}\text { Saya merasa aman / biasa-biasa saja bila obat yang saya minum } \\
\text { tanpa resep dokter (beli sendiri) misalnya obat tekanan darah } \\
\text { tinggi atau obat sakit / nyeri karena reumatik }\end{array}$ & 22 & 23 \\
\hline 8 & $\begin{array}{l}\text { Berjalan / melakukan aktifitas fisik selama } 30 \text { menit baik untuk } \\
\text { lansia }\end{array}$ & 22 & 24 \\
\hline 9 & Saya tidak memiliki pantangan makanan di masa lansia & 22 & 25 \\
\hline 10 & $\begin{array}{l}\text { Tekanan darah tinggi adalah penyakit yang sering di jumpai pada } \\
\text { lansia }\end{array}$ & 23 & 24 \\
\hline 11 & Lansia juga bisa sehat sejahtera lahir dan batin & 22 & 25 \\
\hline 12 & $\begin{array}{l}\text { Lansia penting menkonsumsi makanan tinggi serat seperti buah } \\
\text { dan sayur serta susu tinggi kalsium }\end{array}$ & 25 & 26 \\
\hline 13 & Lansia yang sakit-sakitan biasanya sulit untuk sembuh kembali & 20 & 27 \\
\hline
\end{tabular}


14 Lansia juga butuh hiburan / rekreasi $\quad 22 \quad 23$

15 Ketika lansia, khususnya pada perempuan lebih sering marah- $24 \quad 25$ marah

mean $22,73 \quad 24,47$

Berdasarkan tabel 2 di atas diuraikan bahwa setiap item pernyataan dalam

kuesioner bila dibandingkan skor pre dan post mengalami peningkatan skor. Peningkatan skor tertinggi adalah item penyataaan nomor 13 yang mengalami peningkatan 7 skor sementara item pernyataan nomor 1 tidak mengalami perubahan skor dan terdapat pernyataan yang mengalami peningkatan 1 skor, 2 skor dan 3 skor

Untuk mengetahui perbedaan mean skor pengetahuan lansia setelah dilakukan pretest dan post test serta melihat pengaruh pemberian penyuluhan kesehatan dengan menggunakan media power point diuraikan dalam tabel 3 berikut ini :

Tabel 3.Hasil uji beda pengatahuan lanjut usia sebelum sesudah diberikan penyuluhan kesehatan

\begin{tabular}{|c|c|c|c|c|c|}
\hline Variabel & & ean & & D & p-value \\
\hline \multirow[b]{2}{*}{ Pengetahuan } & Pre & Post & Pre & Post & 0.000 \\
\hline & 22,73 & 24,47 & 1,335 & 1,125 & \\
\hline
\end{tabular}

Sumber : data primer

Berdasarkan tabel 2 di atas mean skor pre test pengetahuan lansia sebelum dilakukan penyuluhan dengan menggunakan media power point adalah 22,73 sementara mean skor hasil post test adalah 24,47, hasil t-test dependen menunjukkan nilai 0.000 yang menunjukkan bahwa adanya pengaruh pemberian penyuluhan kesehatan dengan menggunakan media power point terhadap pengetahuan lansia.

\section{Pembahasan}

Lansia merupakan kelompok yang rentan terhadap masalah kesehatan. Peningkatan pengetahuan tentang kesehatan lansia merupakan salah satu upaya mempertahankan produktifitas lansia. Pemberian promosi kesehatan melalui penyuluhan kesehatan atau pendidikan kesehatan merupakan bagian dari strategi intervensi dalam keperawatan komunitas selain proses kelompok, pemberdayaan dan kemitraan. Bentuk promosi kesehatan dengan kegiatan pendidikan kesehatan ditujukan sebagai diseminasi informasi, 
Haris : Peningkatan Pengetahuan Lanjut Usia melalui Pendidikan Kesehatan

mendorong seseorang untuk berprerilaku hidup sehat atau mengurangi faktor risiko, membuat perubahan perilaku yang dapat meningkatkan kualitas hidup (Riasmini dkk, 2017).

Berdasarkan hasil uji t-test dependen menunjukkan nilai 0.000 yang berarti bahwa pemberian penyuluhan kesehatan dengan menggunakan media power point menunjukkan pengaruh yang signifikan terhadap pengetahuan lanjut usia. Peningkatan pengetahuan lanjut usia ini dengan pemberian penyuluhan kesehatan sesuai dengan hasil penelitian oleh Wardani dkk (2018) dan Candrasari dan Widyasari (2013) yang menunjukkan bahwa pemberian pendidikan kesehatan dapat meningkatkan pengetahuan lansia. Pada kedua penelitian tersebut media yang digunakan saat pemberian pendidikan kesehatan adalah power point namun tidak spefisik disebutkan pada judul penelitian. Sementara menurut Sumardino (2016) Pemberdayaan lansia melalui pendidikan kesehatan dapat meningkatkan pengetahuan lansia dan kemampuan untuk mendeteksi dini penyakit degeratif dan penyakit tidak menular pada lansia.

Dalam promosi kesehatan selain kegiatan penyuluhan kesehatan maka harus didukung dengan kegiatan pemberdayaan masyarakat, kemitraan dan advokasi. Sesuai dengan semangat piagam Ottawa tahun 1986 untuk peningkatan kesehatan melalui promosi kesehatan, yang mencakup adanya kebijakan yang berwawasan kesehatan, lingkungan yang mendukung, reorientasi pelayanan kesehatan, keterampilan individu dan gerakan masyarakat. Promosi kesehatan menjadi langkah awal dalam perubahan perilaku kesehatan sehingga masyarakat memiliki kondisi kesehatan yang optimal. Peningkatan kesehatan menjadi tanggung jawab bersama dengan mempertimbangkan aspek sosial ekonomi dan budaya. Kegiatan promosi kesehatan menjadi tanggungjawab bersama antar lintas sektoral yang ada dan menjadi kegiatan yang berkesinambungan sehingga tujuan pembangunan kesehatan dapat tercapai tanpa adanya perbedaan (kesetaraan).

Kegiatan pengabdian masyarakat ini merupakan langkah awal kegiatan untuk meningkatkan kesehatan lansia di kelurahan Mamburungan Timur. Pengabdian masyarakat masih difokuskan pada kegiatan penyuluhan dengan menggunakan media power point. Sementara hasil screaning kesehatan telah disampaikan kepada pemegang program penyakit tidak menular dan pemegang program kesehatan lansia di Puskesmas 
Mamburungan dan dalam kegiatan ini belum belum dilakukan secara berkesinambungan seperti pemantauan aktifitas keseharian lansia dalam meningkatkan kesehatan. Kedepannya kegiatan pembinaan kesehatan lansia di kelurahan Mamburungan Timur menjadi tanggung jawab bersama lintas sektoral yang ada baik dari akademi keperawatan kaltara, puskesmas Mamburungan dan kelurahan Mamburungan timur keterlibatan sumber daya kesehatan yang ada seperti kader kesehatan.

\section{Simpulan}

Kegiatan pengabdian kepada masyarakat ini menunjukkan adanya pengaruh pemberian penyuluhan kesehatan dengan menggunakan power point terhadap pengetahuan lanjut usia tentang kesehatan di masa lanjut usia. Selama pelaksanaan pendidikan kesehatan juga melibatkan mahasiswa sebagai fasilitator yang membantu menjelaskan isi dan maksud kuesioner saat dilaksanakan pretest dan post test. Saran dari pengabdian pada masyarakat ini diharapkan puskesmas khususnya pemegang program lanjut usia dapat menindaklanjuti hasil pengabdian kepada masyarakat ini dengan melakukan kegiatan pendampingan sebagai upaya meningkatkan derajat kesehatan lanjut usia melalui kegiatan promosi kesehatan seperti pendidikan kesehatan.

\section{Ucapan Terimakasih}

Terimakasih kepada Pimpinan Akper Kaltara serta mahasiswa Akper Kaltara yang tergabung dalam kepanitian social project Akper Kaltara tahun 2019 yang terlibat dalam kegiatan skrening kesehatan pada lansia pada pengabdian masyararakat ini dan semua pihak yang membantu kelancaran kegiatan ini.

\section{Daftar Pustaka}

Brock and Joglekar. (2011). Empowering Power point: Slides and teaching effectiveness. Interdisciplinary Journal of Information, Knowledge, and Management, 6:85-94.

Haber, D. (2010). Health Promotion and Aging, practichal and application for health profesional. New York: Spinger Publishing Compeny. 
Haris : Peningkatan Pengetahuan Lanjut Usia melalui Pendidikan Kesehatan

Dahlan, S. (2011). Statustik Untuk Kedokteran dan Kesehatan. Jakarta: Penerbit Salemba Jakarta.

Khoiron. (2014). Efektifitas Pendidikan Kesehatan Dengan Menggunakan Media Leaflet Dan Media Slide Power Point Terhadap Perubahan Pengetahuan, Sikap Dan Perilaku Deteksi Dini Kanker Serviks Pada Ibu-Ibu PKK Di Wilayah Kerja Puskesmas Kartasura Sukoharjo. Skripsi thesis, Universitas Muhammadiyah Surakarta. http://eprints.ums.ac.id/28620/.

Puspitha, A., Nurdin, N., \& Saleh, U. (2019). Pendampingan Posyandu Lanjut Usia. Media Karya Kesehatan, 2(1) : 74-84.

Riasmini., dkk. (2017). Panduan Asuhan Keperawatan Individu, kelompok dan komunitas berdasarkan modifikasi NANDA, ICNP, NOC dan NIC di Puskesmas dan masyarakat. Ikatan perawat Kesehatan Komunitas Indonesia (IPKKI). Depok; UI Press.

Simanjuntak, S. M., \& Nurnisa, I. N. (2019). Peningkatan Pengetahuan dan Sikap Ibu Tentang Imunisasi dengan Pendekatan Promosi Kesehatan Tentang Imuniasi Dasar. Media Karya Kesehatan, 2(1) : 38-52.

Sumardino, W. (2016). Pemberdayaan Kemampuan Lansia dalam Mendeteksi penyakit degenerative. Jurnal Terpadu Ilmu Kesehatan (Interest) 5 (2) : 230-237.

Wardani, R., dkk. (2018). Pengaruh pendidikan kesehatan Hipertensi terhadap pengetahuan Lansia di Posyandu Lansia Kelurahan Manisrenggo. Journal of Community Engagement in Health. 1 (2).

Widyasari dan Candrasari. (2010). Peningkatan pengetahuan tentang hipertensi pada Lansia di Posyandu Lansia Dukuh Gantungan desa Makamhaji Kartasura Sukoharjo. WARTA, 13(1): 28-36.

Statistik Nasional Kota Tarakan.(2018). Statistik Daerah Kota Tarakan Tahun 2018.

BPS Kalimantan Utara. (2018). Jumlah penduduk menurut kelompok umur dan jenis kelamin di Kalimantan utara tahun 2015-2017. https://kaltara.bps.go.id/dynamictable/2017/02/21/2/jumlah-penduduk-menurutkelompok-umur-dan-jenis-kelamin-di-provinsi-kalimantan-utara-2015.html diakses tanggal 8 Juli 2019.

BPHN. (1998). Undang-Undang RI nomor 13 tentang kesejahteraan lanjut usia.

Promkes. Kemkes. (2019). Kategori media Promosi kesehatan. http://promkes.kemkes.go.id/pencarian_media diakses 8 Juli 2019. 
Haris : Peningkatan Pengetahuan Lanjut Usia melalui Pendidikan Kesehatan

Infodatin Kemenkes RI. (2016). Situasi Lanjut Usia di Indonesia, dalam rangka hari lanjut usia nasional 25 Mei.

Kemkes RI. (2017). Analisis Lansia di Indonesia. Pusat data dan Informasi Kemenkes.

Kemkes RI. (2011). Promosi Kesehatan di daerah bermasalah kesehatan, panduan bagi petugas kesehatan di Puskesmas.

WHO. (2019). The Ottawa Charter for Health Promotion. https://www.who.int/healthpromotion/conferences/previous/ottawa/en/ diakses tanggal 1 juli 2019. 